\title{
Sandfles of the south part of Ouagadougou City, Burkina Faso
}

\author{
SANGARE I.*, GANTIER J.C.**, KOALAGA G.*, DENIAU M.***, OUARI A.* \& GUIGUEMDÉ R.T.*
}

\section{Summary:}

Since 1996, the number of cases of cutaneous leishmaniasis has increased dramatically in Ouagadougou. Leishmania major, zymodeme MON74 was the only strain isolated in this focus. An epidemiological study of the phlebotomine sandflies fauna has been undertaken. Collections of sandflies have been carried out in six areas of the town during one year with two intensive collections at the end of the dry (May-June) and wet seasons (September-October). The only species of genus Phlebotomus captured was $P$. duboscai. This represented $11.2 \%$ from the 4,676 collected sandflies. P. duboscai is a well known vector of L. major, nevertheless, none of the collected sandflies were infected with L. major. 16 species of Sergentomyia were present in the south area of Ouagadougou and S. schwetzi was the most abundant sandfly.

KEY WORDS : Phlebotomus duboscai, Sergentomyia, Leishmania major, Burkina Faso, epidemiology.
Résumé : PhlÉbotomes de la zone Sud de Ouagadougou, BURKINA FASO

Depuis 1996, le nombre de cas de leishmanioses cutanées n'a cessé d'augmenter dans la capitale du Burkina Faso,

Ouagadougou. Un seul zymodème de Leishmania major a été mis en évidence dans ce foyer, le MON74. Pour débuter les études épidémiologiques, un recensement de la faune phlébotomienne a donc été entrepris. Pour mener à bien les captures, six zones ont été déterminées dans la ville ainsi qu'au sud de l'agglomération, en fonction du nombre de cas de leishmanioses signalés. Les captures se sont déroulées sur une année avec une recherche plus intensive à la fin de la saison sèche (mai-juin) et la fin de la saison humide (septembre-octobre). Une seule espèce appartenant au genre Phlebotomus a été capturée. Il s'agit de P. duboscqi qui représente 11,2\% des 4676 insectes capturés. Aucune femelle de cette espèce n'a été trouvée infectée par le parasite, L. major. 16 espèces appartenant au genre Sergentomyia ont également été identifiées. S. schwetzi est l'espèce la plus représentée.

MOTS CLÉS : Phlebołomus duboscqi, Sergentomyia, Leishmania major, Burkina Faso, épidémiologie.

Collections of sandflies have been carried out in six areas of the town, selected for the highest number of ZCL among the inhabitants. The areas were referenced by a geographical information system (Openshaw, 1996). Collections were carried out once a month during one year from October 2005 to September 2006, using on average four CDC mini-traps (Center for Disease Control) (Fig. 1). They were made during the night from $6 \mathrm{pm}$ to $6 \mathrm{am}$. Also, point trappings were performed in the same area but inside homes during presumed periods of transmission of the parasite. CDC mini-traps and buccal aspirators were used. Commercial aerosol of pyrethrin was also applied for 20 seconds in the homes and especially in the bedrooms. The insects were collected on a white sheet. Living specimens of female $P$. duboscqi were dissected. Anterior abdomen and medium gut were cultivated in NNN medium when leishmanial promastigotes were suspected. Dissected thorax and anterior abdomens were stored in analytical grade $70 \%$ ethanol for PCR detection of Leishmania infections. Pharynx and genitalia of the whole specimens were slide-mounted. These specimens were treated and identified according to Abonnenc \& Minter (1965), Abonnenc, (1972), David- 


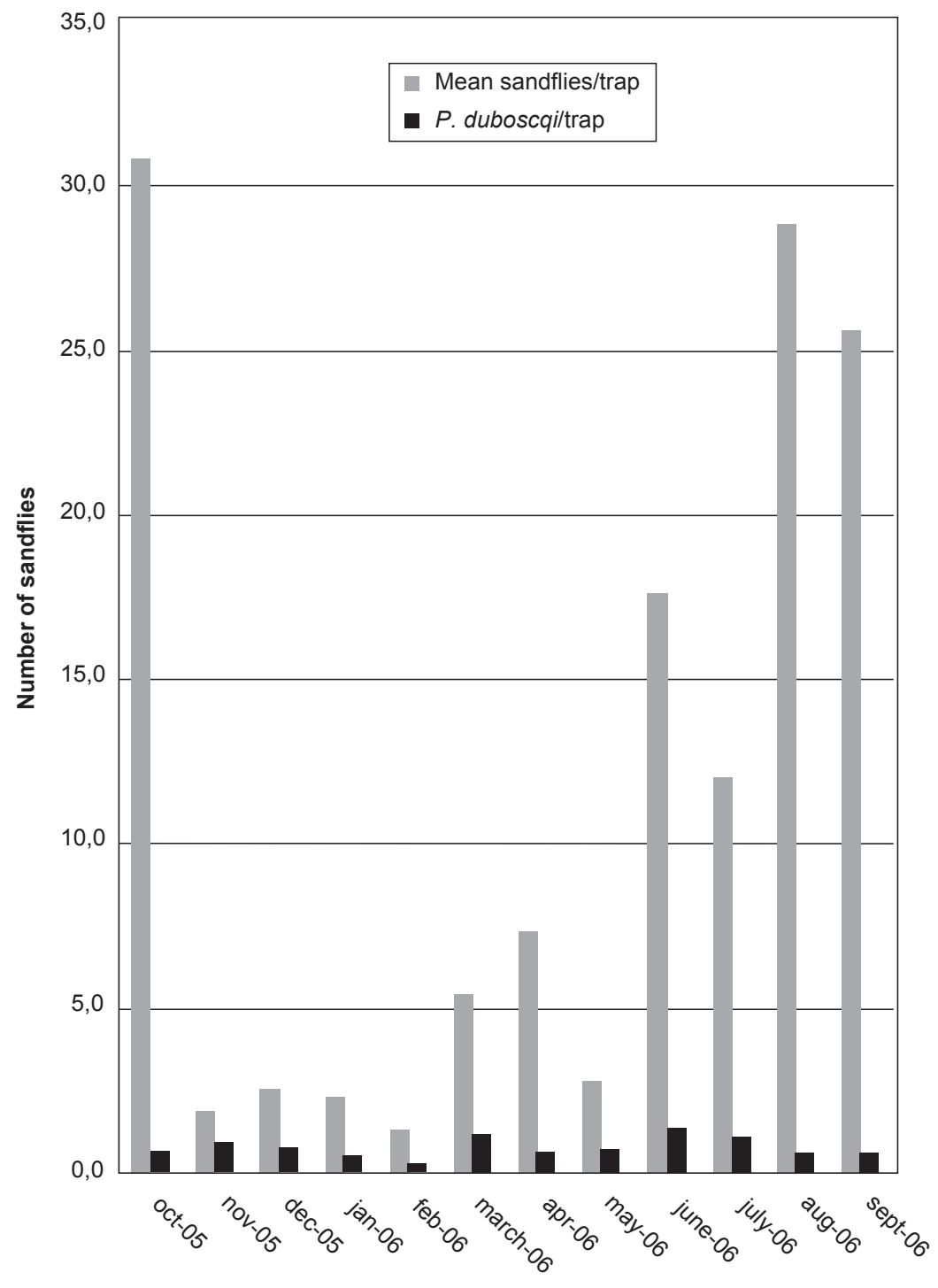

Fig. 1. - Number of trapped sandflies during the longitudinal study (the dramatic percentage of Sergentomyia versus Phlebotomus genus is pointed). son, (1990) and to the recent review of Niang et al. (2004).

The longitudinal study showed that the only species of genus Phlebotomus collected was P. duboscqi. It represented $6.4 \%$ from the 3,836 trapped specimens. But no specimen of $P$. duboscqi was infected with promastigotes.

The cumulated result and the percentage of every trapped species of trappings (yearly longitudinal and the two intensive collections at the end of the wet and dry seasons) are showed in Table I. The increased percentage of $P$. duboscqi (11.2\% from the 4,676 trapped specimens) was probably due to trappings in the homes. 16 species of the genus Sergentomyia were present in the south area of Ouagadougou. Sergentomyia schwetzi was the most abundant sandfly and it has been found in all areas and represents more than $54 \%$ of the sandflies captured. Its both typical and atypical forms were present with a predominance of the last form. The other dominant sandflies of the genus Sergentomyia were $S$. antennata (7\%) and S. adleri (7\%) (Table I). In this first study, only the areas of suspected transmission were investigated. Species trapped during this study did not differ from species known in Burkina Faso (Abonnenc \& Pastre, 1971), (Maroli et al., 1986); moreover, $P$. duboscqi was the only species identified of the genus Phlebotomus. No density comparison can be carried out with previous studies because the trapping methods were different. In our study, the density of $P$. duboscq $i$ was similar outside and inside the human dwellings. For this reason, this species could be considered as a probable main vector of Leishmania sp. This species is present all year long but with a low density as shown in Figure 1. This relative scarcity does not exclude that this species could be vector of ZCL as shown in Senegal (Desjeux et al., 1981). 


\begin{tabular}{lc}
\hline \multicolumn{1}{c}{ Species } & Relative frequency (\%) \\
\hline P. duboscqi & 11.25 \\
S. inermis & 1.09 \\
S. squamipleiris & 0.77 \\
S. ghesquieri & 0.41 \\
S. schwetzi & 54.79 \\
S. berreri & 3.06 \\
S. bedfordi & 2.91 \\
S. antennata & 7.51 \\
S. buxtoni & 2.03 \\
S. fallax & 0.77 \\
S. dubia & 0.28 \\
S. magna & 1.41 \\
S. africana & 1.80 \\
S. adleri & 7.21 \\
S. affinis-vorax & 2.50 \\
S. christophersi & 1.75 \\
S. clydei & 0.47 \\
\hline
\end{tabular}

Table I. - List and percentage of different species of phlebotomine sandflies trappings (yearly longitudinal and intensive collections at the end of the rainy and dry seasons) from October 2005 to September 2006.

We did not capture specimens of $P$. longicuspis that we found in 2003 in this town but we have confirmed the presence of Sergentomyia christophersi in Burkina Faso (Depaquit et al., 2005). However, this species trapped in a cattle transit zone in Hamdalaye sector was not investigated in this study.

In the sub-genus Sergentomyia presents in Burkina Faso, only $S$. schwetzi is known for its anthropophilic behavior. Other species known for biting humans are S. magna, $S$. africana and some species of the sub-genus Sintonius, S. adleri, S. affinis-vorax or S. clydei. We were surprised by the high proportion of $S$. schwetzi and by the presence of the typical and atypical forms of this species. The variation of seasonal density of $S$. chwetzi was comparable to that observed by Abonnenc (1972) in Dakkar. According to Davidson (1990), we consider this species as complex, requiring modern studies of genotypic tags.

S. schwetzi is not considered as a vector of Leishmania sp. despite its anthropophilic behavior. Parrot et al. (1945) had considered this possibility in 1943 but Lawyer et al. (1990) could not obtain infectious leishmanial promastigotes from S. schwetzi.

Nevertheless, we shall have to complete the investigation of the whole city and concentrate the work on the dissection of P. duboscqi and other different Sergentomyia female species.

\section{ACKNOWLEDGEMENTS}

This work was supported by a grant of the French Ministère des Affaires Étrangères: a CORUS project $n^{\circ} 02313025$.

\section{REFERENCES}

ABonnenc E. Les Phlébotomes de la région éthiopienne (Diptera, Psychodidae). Mémoire ORSTOM, 1972, 55, 1-289

Abonnenc E. \& Minter D.M. Tables d'identification bilingues des phlébotomes de la région éthiopienne. Cabier de l'ORSTOM, série Entomologie Médicale, 1965, 5, 1-63

Abonnenc E. \& Pastre J. Phlébotomes de la Haute-Volta (Diptera, Psychodidae), notes biologiques. Cahier de l'ORSTOM, série Entomologie Médicale, 1971, 9, 387-416.

DAvidson I. Sandflies of Africa south of the Sahara; taxonomy and systematic of the genus Sergentomyia. South African Institute for Medical Research, Johannesburg, 1990, 78 p.

Depaquit J., Muller F., Gantier J.C., Léger N., Ferté H., Ready P. \& Niang A.A. Phlebotomine sandflies from Ouagadougou, Burkina Faso: first record of Phlebotomus (Larroussius) longicuspis south of the Sahara. Medical \& Veterinary Entomology, 2005, 19, 322-325.

Desjeux P. Waroquy I. \& Dedet J.P. La leishmaniose cutanée en Afrique de l'Ouest. Bulletin de la Société de Pathologie Exotique, 1981, 4, 414-425.

Guiguemde R.T., Sawadogo O.S., Bories C., Traore K.L., Nezien D., Nikiema L., Pratlong F., Marty P., Houin R. \& DeNIAU M. Leishmania major and HIV co-infection in Burkina Faso. Transactions of the Royal Society of Tropical Medicine \& Hygiene, 2003, 97, 168-169.

Lawyer P.G., Ngumbi P.M., Anjili C.O., Odongo S.O., Mebrahtu Y.B., Githure J.I., Koech D.K. \& Roberts C.R. Development of Leishmania major in Phlebotomus duboscqi and Sergentomyia schwetzi (Diptera: Psychodidae). American Journal of Tropical Medicine \& Hygiene, 1990, 43, 31-43.

Maroli M., Fausto A.M., Sabatinelli G. \& Majori G. Phlebotomines (Diptera, Psychodidae) from Burkina Faso. A note on the sandfly species collected in domestic resting sites. Annales de Parasitologie Humaine et Comparée, 1986, 61, 683-688.

Niang A.A., Hervy H.P., Depaquit J., Bousses P., Davidson I., Geoffroy B., Léger N., Trouillet J., Killick-Kendrick R., KilLicK-Kendrick M., Rioux J.A. \& Brunhes J. Les Phlébotomes de la région afro-tropicale : logiciel d'identification et d'enseignement. Pub Scient IRD, 2004, ISBN 2-7099-1499-9, ISSN 1142-2580.

OpENSHAW S. Geographical information systems and tropical diseases. Transactions of the Royal Society of Tropical Medicine \& Hygiene, 1996, 90, 337-339.

Parrot L., Mornet J. \& Cadenat J. Notes sur les Phlébotomes XLVIII. Phlébotomes de l'Afrique Occidentale Française, I. Sénégal, Soudan, Niger. Archives de l'Institut Pasteur d'Algérie, 1945, 23, 232-244.

Rıoux J.A. Mission épidémiologique au Nord Tchad. Comité de Coordination Scientifique du Sahara, Arts \& Métiers Graphiques, Paris, 1960, 132 p.

Traoré K.S., Sawadogo N.O., Traoré A., Ouedraogo J.B., Traoré K.L. \& Guiguemde T.R., Preliminary study of cutaneous leishmaniasis in the town of Ouagadougou from 1996 to 1998. Bulletin de la Société de Pathologie Exotique, 2001, 94, 52-55.

Reçu le 22 septembre 2008 Accepté le 25 juin 2009 